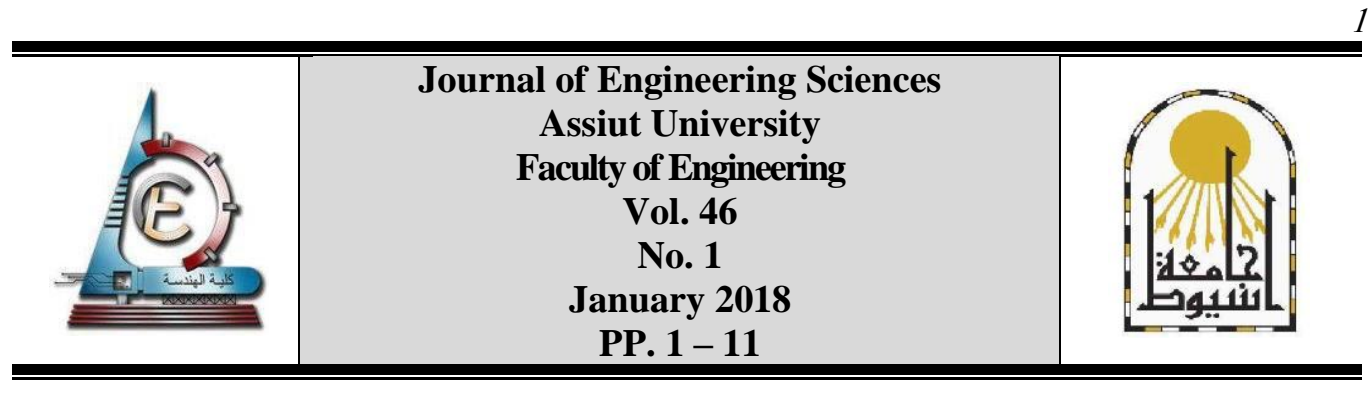

\title{
INVESTIGATION ON IMPROVING RIGID PAVEMENT PROPERTIES BY ADDING RECYCLED RUBBER
}

\author{
Al Sayed M. Abdullah, Ghada S. Mousa, \\ Zainab E. Abd El-Shafy, Mohamed Ashour Mohamed
}

Civil Engineering Department, University of Asyut

Received 6 November 2017; Accepted 28 November 2017

\begin{abstract}
In this study different mechanical, physical and durability tests were manufactured to investigate the effect of recycled rubber as a partial replacement of fine aggregate by volume on the properties of plain concrete pavements (PC). First step of this paper, the slump, flexural and compression tests are carried out for trial batches to choose airfield PC mix. The second step, the slump, flexural and compression tests are carried out to select the optimum percentage of rubber as a partial replacement of fine aggregate by volume. Afterward, the tests of slump, compression, three point bending of single edge notched beam, splitting, flexural, impact, ultrasonic pulse velocity, Schmidt hammer, electric resistivity, water absorption and abrasion resistance were performed. Results of the experimental study indicated that the addition of rubber recorded significant to slight improvement in the mechanical, some physical and some durability properties of PC. Slight reduction in other properties of PC was observed.
\end{abstract}

\section{Introduction}

All civil infrastructures have a definite life span and all structures are designed to fail at some point, and this includes the vast network of road pavements [1]. Plain Concrete is widely used in concrete pavement construction. It has excellent strengths, but poor tensile strength and very low elasticity and when strength increases, elasticity decreases. It is desirable for concrete pavement to have both relatively high tensile strength and elasticity [2]. Plain concretes are representative materials for both the construction and maintenance of pavements. They have good mechanical characteristics with a cheap price. However, they also have multiple drawbacks such as shrinkage, bad chemical resistance, and low tensile strength, which shorten the life expectancy of runway and pavements [3]. Low volume of traffic on airfields relative to most road situations increased the tendency of sealing aggregates to "polish" [4]. Discrete cracks exist in most concrete structures such as rigid pavements. Concrete cracks are caused by many factors such as humidity and temperature differences, mechanical loading, and chemical attack. Small or large crack openings can lead to premature concrete deterioration [5]. Intensive effort was devoted to enhance the performance of concrete pavement surface to prolong the service life and give superior durability of pavement [6]. One billion end-of-life tires are generated globally each year, on other hand there is a lack of aggregate resources in some sites and countries [7]. With realization a lot of environmental benefits, researchers suggest that rubberized concrete (RC) 
is more flexible than standard concrete pavement, serve as sustainable and cost effective solutions for improved rigid pavement [2]. The objective of this study is to evaluate the behavior of rubberized concrete pavement by evaluate the mechanical, physical and durability properties through destructive and nondestructive tests. Therefore, this study is conducted to improve the pavement properties and reduced concrete pavement maintenance cost. This approach is of great importance to the economic and environmental impacts.

\section{Experimental work}

Experimental work deals with the description of the test program including used materials, test procedures, test specimens, and instrumentations. The following tests procedures are taken to evaluate the behavior of rubberized concrete Pavement.

\subsection{Materials and mixing procedure}

Type I Portland cement with grade of $42.5 \mathrm{~N}$ was used. Local natural sand and crushed gravel from Assuit were used as fine and coarse aggregates respectively. Recycled rubber of (0.85-3.5) mm was produced by Sama United Recycling factory in Ismailia was used as a partial replacement of sand by volume. Drinking water was used for both mixing and curing. High-range water reducing admixture (HRWRA) CMB addicrete BVF was provided by CMB Co. Assiut was used. Physical and chemical properties of the used materials are listed in Table 1. All materials were tested according to the ECP203 [8].

Table 1.

Physical and chemical properties of the used aggregates.

\begin{tabular}{|c|c|c|c|c|}
\hline property & sand & Gravel 1 & Gravel 2 & Rubber \\
\hline $\begin{array}{c}\text { Volume weight in } \\
\text { loose state }\left(\mathrm{t} / \mathrm{m}^{3}\right)\end{array}$ & 1.45 & 1.2 & 1.28 & 0.41 \\
\hline $\begin{array}{c}\text { Volume weight in } \\
\text { compacted state }\left(\mathrm{t} / \mathrm{m}^{3}\right)\end{array}$ & 1.63 & 1.43 & 1.48 & 0.6 \\
\hline Specific gravity & 2.50 & 2.77 & 2.63 & 1.2 \\
\hline \% Absorption & 1.0 & 1.13 & 1.17 & - \\
\hline \% Fine Materials & 2.0 & 0.5 & 0.63 & - \\
\hline \% Crushing Value & - & 19 & 18 & - \\
\hline$\%$ Loss of wear & - & - & 19 & - \\
\hline Fineness Modulus & 2.2 & 6.0617 & 7.33 & 1.2 \\
\hline \% Chloride ions & 0.041 & 0.018 & 0.032 & - \\
\hline \% Sulphate ions & 0.139 & 0.125 & 0.12 & - \\
\hline PH & 8.78 & 8.50 & 8.50 & - \\
\hline maximum nominal size & - & 10 & 20 & - \\
\hline
\end{tabular}

\subsection{Design of PC mix}

Trial mixtures are prepared to obtain target strengths, a 28-day flexural strength between 4.14 to $5.17 \mathrm{MPa}$ as recommended for most airfield applications and to comply with the requirements of FAA 150/5320-6F and FAA Item P-501 [9,10]. All mixtures possess $\mathrm{w} / \mathrm{c}=0.4$, that may be required for concretes exposed to sulfate soils or waters, freezing and thawing and for protection of reinforcement corrosion [11]. There is a need to 
Mohamed Ashour Mohamed, Investigation on improving rigid pavement properties by adding

use water reducing admixtures to improve the workability [12]. The amounts of materials required to produce $1 \mathrm{~m}^{3}$ of $\mathrm{PC}$ mix are given in Table 2 .

Table 2.

Amount of constitute materials for $1 \mathrm{~m}^{3}$ of the used plain concrete

\begin{tabular}{|c|c|c|c|c|c|c|c|c|}
\hline $\begin{array}{c}\text { Cement } \\
\left(\mathrm{kg} / \mathrm{m}^{3}\right)\end{array}$ & $\begin{array}{c}\text { Water } \\
(\text { Liter/m }\end{array}$ & W/C & $\begin{array}{c}\text { Sand } \\
\left(\mathrm{kg} / \mathrm{m}^{3}\right)\end{array}$ & $\begin{array}{c}\text { Gravel 1 } \\
\left(\mathrm{kg} / \mathrm{m}^{3}\right)\end{array}$ & $\begin{array}{c}\text { Gravel 2 } \\
\left(\mathrm{kg} / \mathrm{m}^{3}\right)\end{array}$ & S/G & G1/G2 & $\begin{array}{c}\text { HRWRA } \\
\left(\mathrm{kg} / \mathrm{m}^{3}\right)\end{array}$ \\
\hline 400 & 160 & 0.4 & 675 & 784 & 422 & 0.56 & $65 / 35$ & 8 \\
\hline
\end{tabular}

\subsection{Rubberized concrete $(R C)$ mix}

Trial mixtures with rubber were prepared to select the rubberized mix, based on the next reasons and trial mixtures as shown in Fig. 1. In this investigation the percentage of rubber used was $10 \%$ replacement of fine aggregate by volume. Concrete with $30 \%$ or more rubber results in difficulty with finishing of rigid pavement surface and should be avoided. Rubber content should be from 8 to $12 \%$, which leads to increase in the energy absorption. So, big content of rubber may have a negative effect on the ductility of the concrete. These remarks are compatible with ref. $[13,14]$.

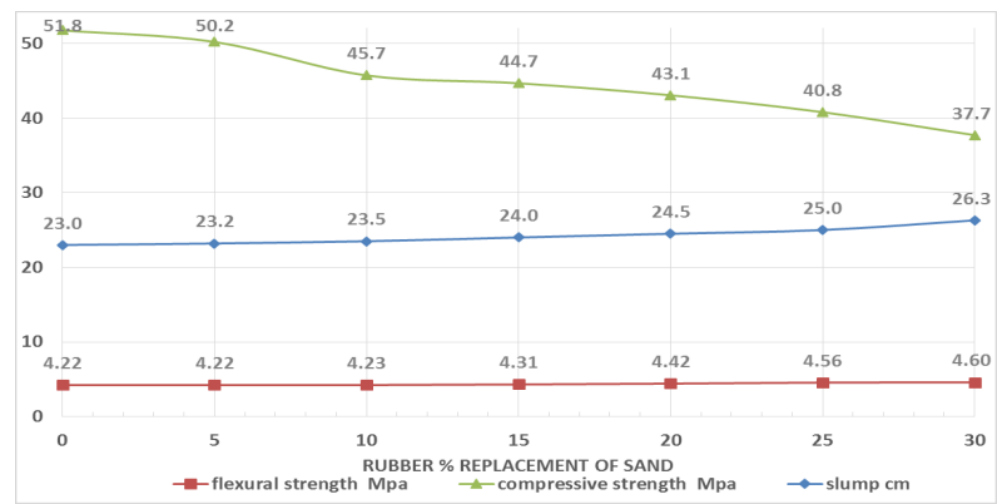

Fig. 1 Trial mixtures as a function of rubber replacement results.

\subsection{Tests for rubberized and plain concretes}

Instrumentation was connected to a computerized data acquisition system (TDS-150) to record the readings at every second of loading during the tests. The load was measured using the load cell with a capacity of $2000 \mathrm{kN}$. The load cell was located under the loading piston of the machine. The vertical deflection of the concrete beam at mid-span was measured by using LVDT of $100 \mathrm{~mm}$ stroke and accuracy $0.00001 \mathrm{~mm}$. Different instrumentation including external devices was used to obtain data during the tests in the experimental program, as shown in Table 3. 


\section{Table 3.}

All tests details

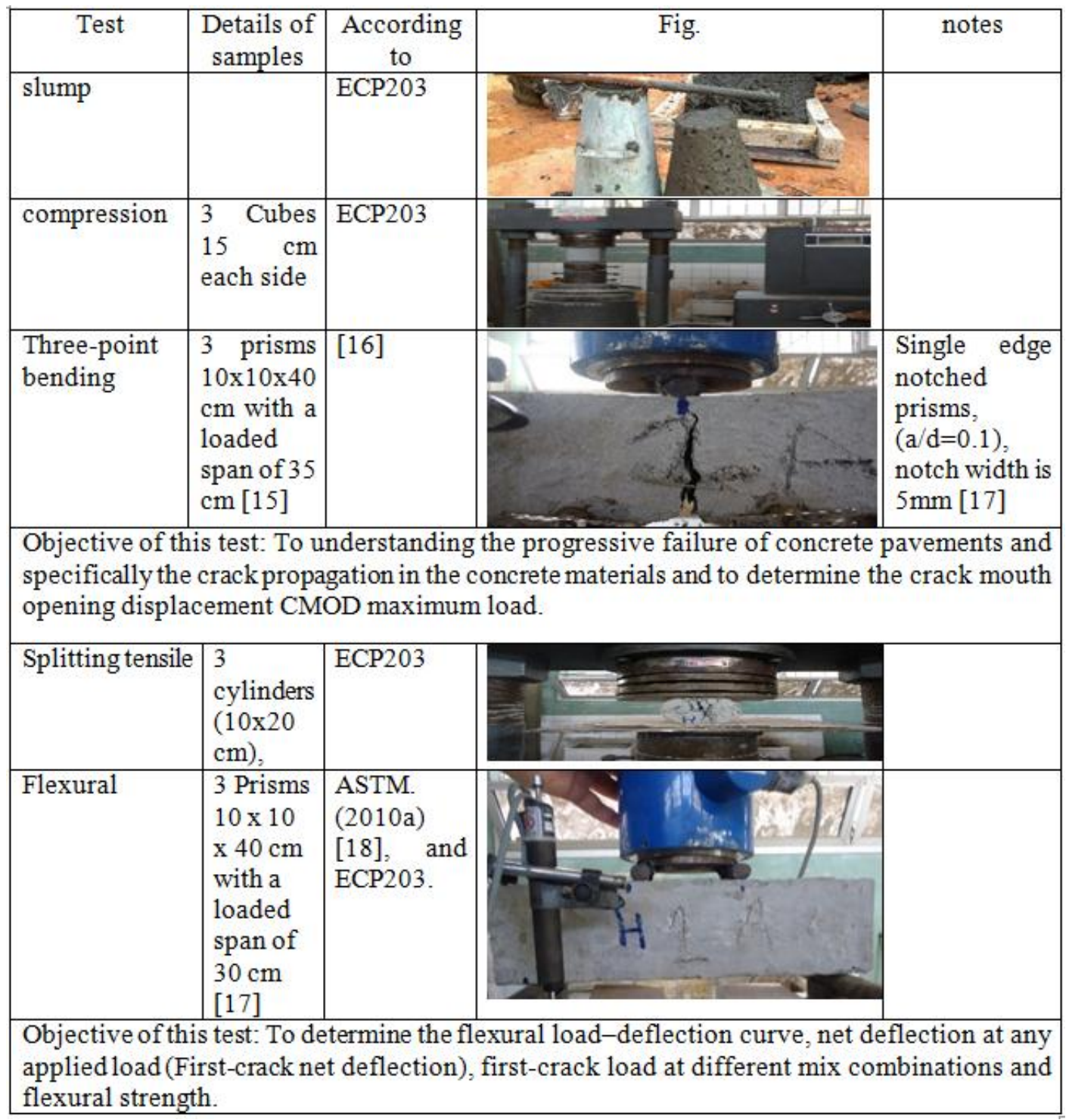


Mohamed Ashour Mohamed, Investigation on improving rigid pavement properties by adding .......

Table 3. (Continue)

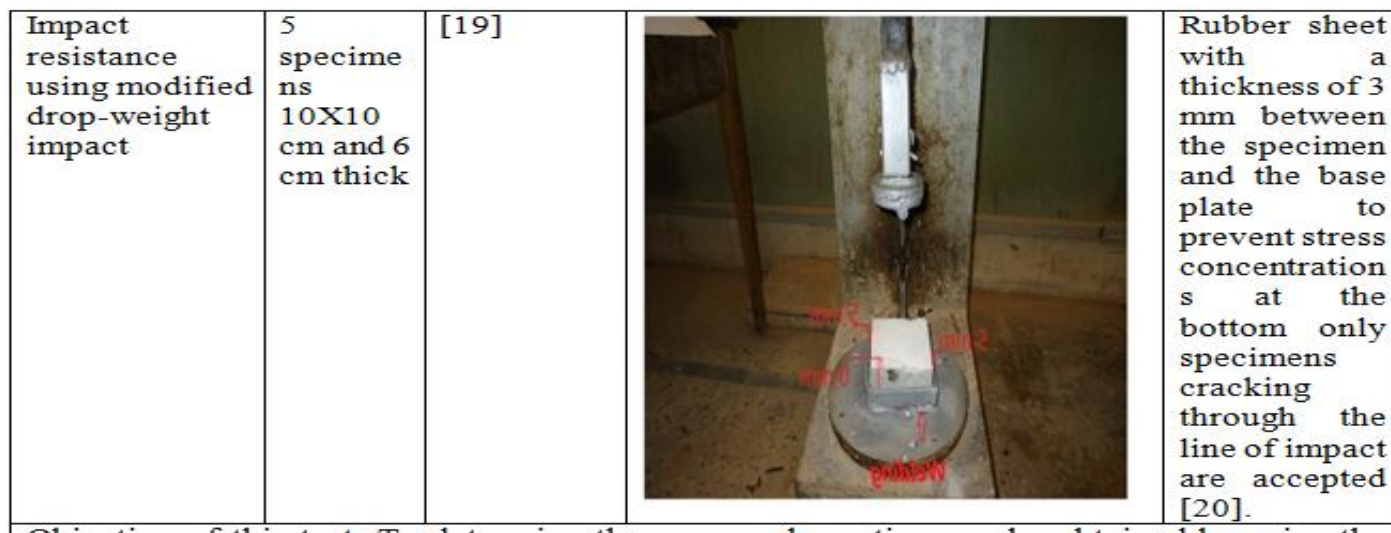

Objective of this test: To determine the energy absorption can be obtained by using the following formula: $E=N x(w \times h)$ joules, where $\mathrm{E}=$ energy in joules, $\mathrm{w}=$ weight in Newton, $\mathbf{h}=$ drop height in meter, $\mathrm{N}=$ blows in numbers. In the above equation, the weight dropping $48.5429 \mathrm{~N}$ (a hammer weighing as $4.45 \mathrm{~kg}$ and Impact piston weighing $0.5 \mathrm{~kg}$ ), the height of fall $0.457 \mathrm{~m}$ were maintained constant throughout the experiment.

\begin{tabular}{|l|l|l|l|}
\hline $\begin{array}{l}\text { Ultrasonic } \\
\text { pulse velocity }\end{array}$ & $\begin{array}{l}3 \text { cubes } \\
10 \\
\text { each side }\end{array}$ & $\begin{array}{l}\text { ASTM } \\
\text { C597 [21] }\end{array}$ & \\
\hline
\end{tabular}

Objective of this test: To determine UPV by direct transmission. The following formula ultrasonic pulse transmission time was determined at $\mathrm{m} / \mathrm{s}: V=L / T$, where $\mathrm{L}$ is transmission distance $(\mathrm{m}), \mathrm{T}$ is transmission time in the concrete (s) and $\mathrm{V}$ is pulse transmission velocity in concrete $(\mathrm{m} / \mathrm{s})$.

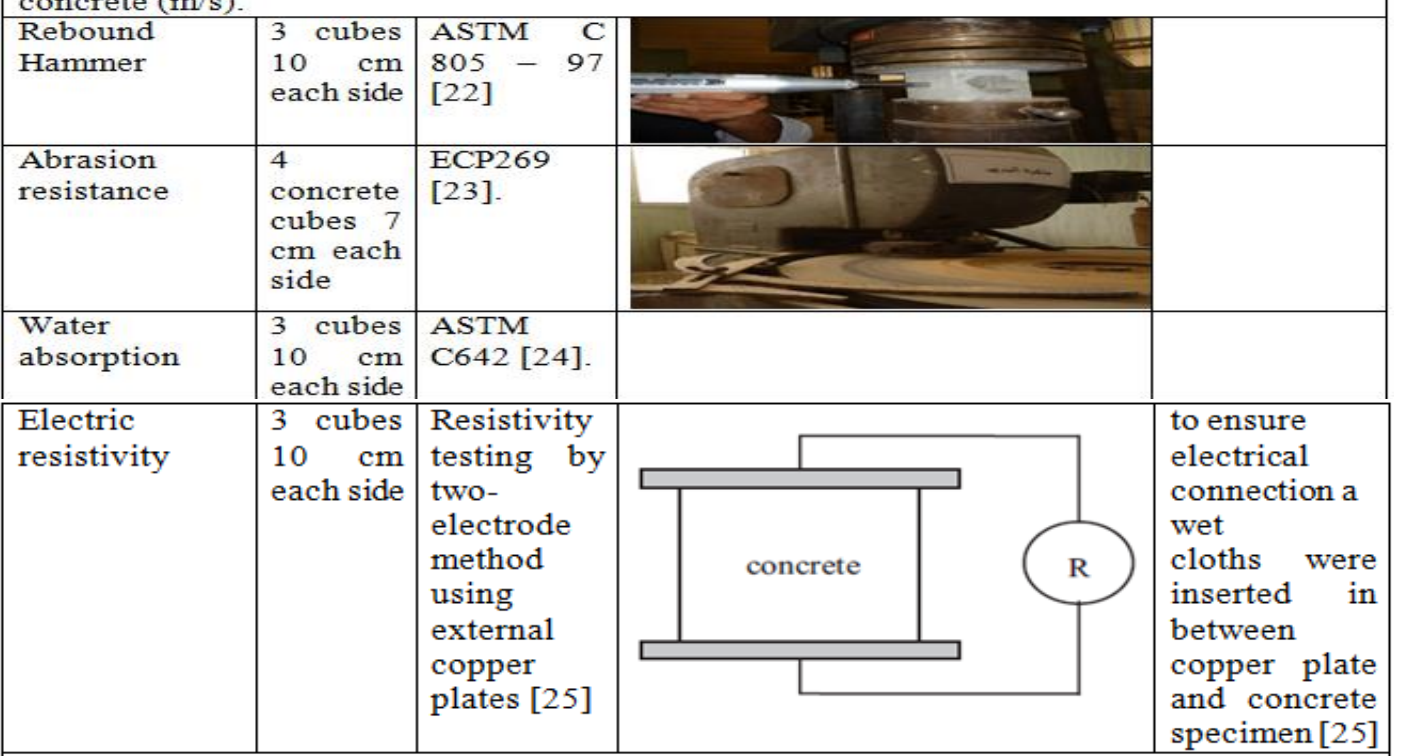

Objective of this test: To determine electrical resistivity of the concrete as follows: $\rho=A^{*} R /$ $L$, where $\rho$ is the resistivity $(\mathrm{k} \Omega \mathrm{cm})$, A the area $(\mathrm{cm} 2)$ of the specimen in contact with plates, $\mathrm{R}$ the resistance $(\mathrm{k} \Omega)$ and $L$ is the length of specimen in the direction of the current $(\mathrm{cm})$. 


\section{Results and discussions}

Table 4 shows the results of all tests. Discussions of these results are presented in the following sections:

\subsection{Slump results}

The workability of fresh-state concrete increased by using rubber as a fine aggregate partial replacement by percentage $2.13 \%$. This may be attributed to three reasons. First, since the rubber particles are much softer than the cement past. Second, rubber did not absorb water at all and most of the rubber floated on the surface of the water. Third, due to the lack if adhesion between the particles of rubber and the cement paste, soft rubber particles behave as voids in the concrete matrix, less water is needed for rubberized concrete to achieve good workability. These remarks are compatible with ref. [26, 27].

\subsection{Compressive strength and hardness results}

The addition of rubber slightly decreased the plain concrete's compressive strength and hardness by percentage 12.89 and $12.53 \%$ respectively because the hardness for rubber is less than that of aggregate. Rubber particles are more flexible and weaker than the cement matrix. Therefore the cracks first of all start developing at the contact zone of the rubber and the cement matrix [28]. So, the maximum rubber percentage is suggested to not exceed $12 \%$ replacement of fine aggregates.

\subsection{Three-Point bending, splitting, flexural strength and impact resistance results}

The addition of rubber increased the plain concrete's CMOD maximum load, splitting strength, first-crack load, first-crack deflection, flexural strength, energy absorption at first crack and at ultimate failure by percentages of 8.41, 8.08, 1.75, 41.67, 1.75, 46.15 and 58.33\% respectively as shown in Fig. 2-4. RC is more flexible than PC. Rubber improved the strain capacity before the macro-crack formation. Rubber can therefore withstand large deformations, as it acts like a spring inside the composite and delays crack widening. Crack tip bridging of rubber within the fracture zone, resulting in the arrest of crack propagation. This phenomenon is described as "strain hardening" in fiber-reinforced concrete under tension, where the tensile behavior has demonstrated the fiber bridging within propagating cracks. The presence of rubber in concrete increased the resistance of concrete to crack initiation under impact load and absorbs vibration to a large extent. Rubber content contributed to increasing the post cracking resistance. As reported by other researchers [29-33].

\subsection{Ultrasonic pulse velocity (UPV) results}

The addition of rubber too slightly decreased the plain concrete's ultrasonic pulse velocity by percentage $2.94 \%$. Because the cavities formed by rubber develops resistance against the transmission of ultrasonic waves and thus passing of waves is attenuated. As referred by [34].

\subsection{Electrical resistivity results}

The addition of rubber increased the plain concrete's electrical resistivity by percentage $15.35 \%$. because it is an insulating material. In general all concretes had high resistance to chloride penetration based on electrical resistivity, $(15-35 \mathrm{k} \Omega \mathrm{cm})$ according to ASTM C1760, and had low corrosion rate (based on electrical resistivity $>20 \mathrm{k} \Omega \mathrm{cm}$ ). Which confirmed with ref? [35 and 36]. 
Mohamed Ashour Mohamed, Investigation on improving rigid pavement properties by adding

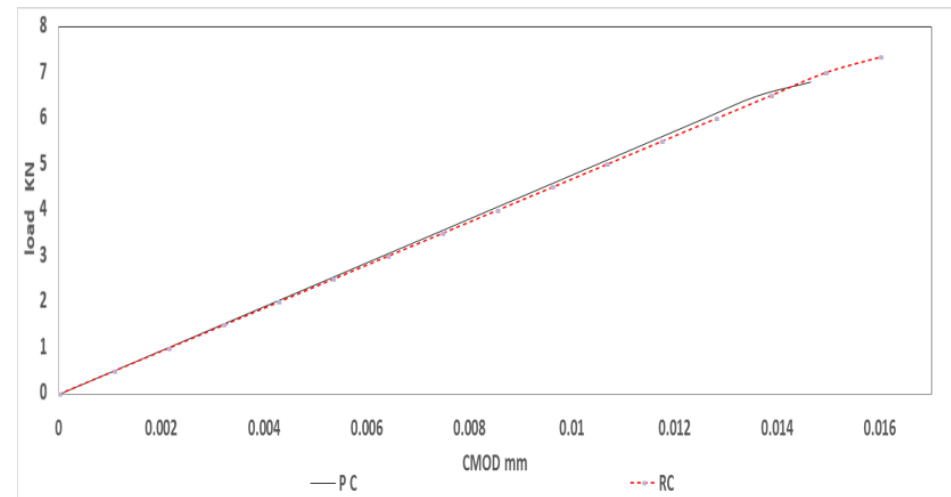

Fig. 2. Load-CMOD behavior for notched specimens

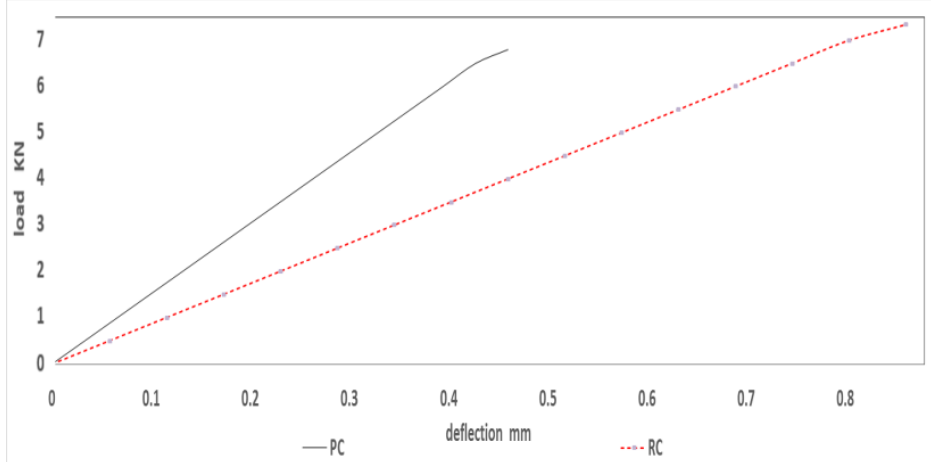

Fig. 3. Load-deflection behavior for notched specimens

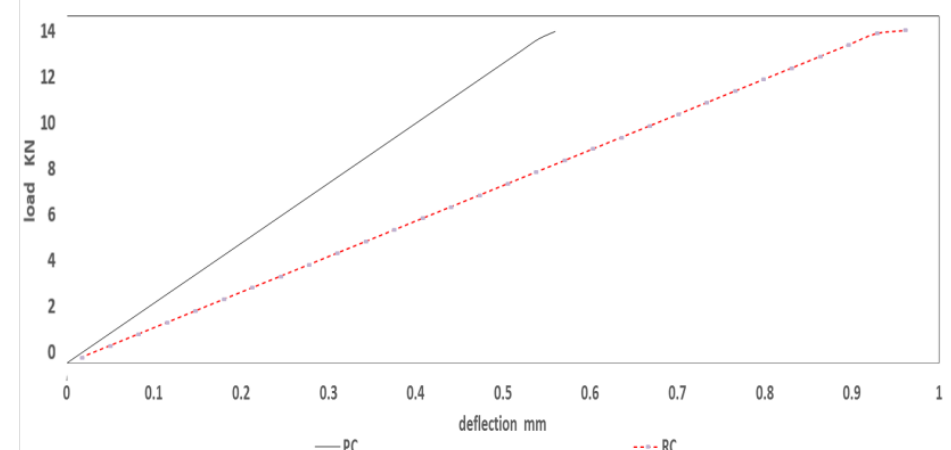

Fig. 4. Load-deflection behavior for unnotched specimens

\subsection{Water absorption results}

The addition of rubber increased the plain concrete's water absorption by percentage $1.83 \%$. That sand is substituted by rubber which has different shapes and structures, some porosity is formed increasing water absorption. The rubber form effective open pores and capillaries that are easily filled with water. This might have caused the occurrence of micro voids around the surface of the specimen and have enabled more water absorption. These results are compatible with ref. [37].

\subsection{Abrasion resistance results}

The addition of rubber decreased the plain concrete's loss in mass and in thickness by percentage 7.07 and $6.59 \%$ respectively. The rubber is more resistant than the stone 
aggregate, because of its capacity to retain the elastic property during the longer time period of stress. The friction forces occurring during abrasion, on the contact between the abrasive surfaces are not sufficiently high to tear out the rubber from the concrete composite. As referred by [38].

\section{Table 4.}

tests results

\begin{tabular}{|l|c|c|}
\hline \multicolumn{1}{|c|}{ Test name } & Pc & RC \\
\hline Slump cm & 23 & 23.5 \\
\hline Water absorbtion \% & 3.64 & 3.71 \\
\hline Loss in thickness mm & 0.45 & 0.42 \\
\hline Hardness & 46.7 & 41.5 \\
\hline Ultra sonic V m/s & 5882.35 & 5714.29 \\
\hline Loss in mass g & 5 & 4.67 \\
\hline Compressive strength Mpa & 51.8 & 45.89 \\
\hline Flexural strength MPa at First crack-load & 4.12 & 4.19 \\
\hline Splitting strength MPa & 3.06 & 3.33 \\
\hline First crack-load N & 13.73 & 13.97 \\
\hline Deflection at first crack mm & 0.54 & 0.93 \\
\hline The CMOD at the maximum load mm & 0.01 & 0.02 \\
\hline Energy absorption at first crack joules & 155.29 & 288.39 \\
\hline Energy absorption at ultimate failure joules & $\mathbf{2 2 1 . 8 4}$ & $\mathbf{5 3 2 . 4 2}$ \\
\hline Electrical resistivity (k $\Omega$ cm) & $\mathbf{2 6 . 4 2}$ & $\mathbf{3 1 . 2 1}$ \\
\hline
\end{tabular}

\section{Conclusions}

On the basis of results obtained from the present research the following conclusions can be drawn out:

1- The addition of rubber increases the plain concrete's slump.

2- The addition of rubber increases the CMOD at the maximum load for notched specimens, the splitting strength, first-crack load, and the first-crack deflection.

3- With increasing percentage of rubber the flexural strength increased, which contradicts the Empirical results.

4- The energy absorption at first crack, at ultimate failure and electrical resistivity increased with the addition of crumb rubber.

5- The addition of crumb rubber decreased loss in mass and thickness. These results confirm the advantages and necessity of using rubber in pavement construction.

6- The addition of crumb rubber slightly reduces compressive strength, the hardness and ultrasonic pulse velocity but increase water absorption. Therefore we recommended adding some enhancements materials to the rubberized concrete to avoid these defects.

\section{REFERENCES}

[1] BTS/USDOT, Pocket guide to transportation, 2003, Bureau of Transportation Statistics, U.S.

[2] Abaza, O.A. and Hussein, Z.S., 2015. Flexural Behavior of Steel Fiber-Reinforced Rubberized Concrete. Journal of Materials in Civil Engineering, 28(1), p.04015076. 
Mohamed Ashour Mohamed, Investigation on improving rigid pavement properties by adding

[3] Ahmed I, Rahman M, Seraj S, Hoque A. Performance of plain concrete runway pavement. J Perform Const Facil 1998;12:145-52.

[4] Airfield Pavement Maintenance Manual | January 2015 | Re vision E.

[5] Chupanit, P. and Roesler, J.R., 2008. Fracture energy approach to characterize concrete crack surface roughness and shear stiffness. Journal of Materials in Civil Engineering, 20(4), pp.275-282.

[6] Khayat, K.H., Eng, P. and Valipour, M., 2014. Design of ultra-high performance concrete as an overlay in pavements and bridge decks (No. NUTC R321).

[7] Rubber Manufacturers Association, US Scrap Tire Management Summary 2005-2009, Washington, DC; 2011.

[8] ECP committee 203. (2007). "The Egyptian Code for Design and Construction of Concrete Structures", Housing and building research center, Giza, Egypt.

[9] FAA. Item P-501 Portland Cement Concrete (PCC) Pavement.

[10] FAA. 150/5320-6F-2016. Airport Pavement Design and Evaluation.

[11] Prozzi, J.A., 2012. Calibration of HERS-ST for Estimating Traffic Impact on Pavement Deterioration in Texas (No. SWUTC/12/169205-1),University of Texas at Austin.

[12] Sharmila, S. and Thirugnanam, G.S., 2013. Behavior of Reinforced Concrete Flexural Member with Hybrid Fibre under Cyclic Loading. International Journal of Science, Environment and Technology, 2(4), pp.725-734.

[13] Mohammadi, I. and Khabbaz, H., 2015. Shrinkage performance of Crumb Rubber Concrete (CRC) prepared by water-soaking treatment method for rigid pavements. Cement and Concrete Composites, 62, pp.106-116.

[14] Guo, Y.C., Zhang, J.H., Chen, G.M. and Xie, Z.H., 2014. Compressive behaviour of concrete structures incorporating recycled concrete aggregates, rubber crumb and reinforced with steel fibre, subjected to elevated temperatures. Journal of cleaner production, 72, pp.193-203.

[15] Isla, F., Luccioni, B., Ruano, G., Torrijos, M.C., Morea, F., Giaccio, G. and Zerbino, R., 2015. Mechanical response of fiber reinforced concrete overlays over asphalt concrete substrate: Experimental results and numerical simulation. Construction and Building Materials, 93, pp.1022-1033.

[16] Bordelon, A.C., 2007. Fracture behavior of concrete materials for rigid pavement systems (Doctoral dissertation, University of Illinois at Urbana-Champaign).

[17] Mubaraki, M., 2015. Toughness Enhancement of Airfield Concrete Pavement by Using Short Fiber. Journal of Marine Science and Technology, 23(3), pp.373-379.

[18]ASTM. (2010a). "Standard test method for flexural performance of fiberreinforced concrete using beam with third-point loading." C1609, West Conshohocken, PA

[19] Myers, J.J. and Tinsley, M., 2013. Impact Resistance of Blast Mitigation Material Using Modified ACI Drop-Weight Impact Test. ACI Materials Journal, 110(3).

[20] Schrader, E.K., "Impact Resistance and Test Procedure for Concrete," ACI Materials Journal, Vol. 78, No. 2, 1981, pp. 141-146.

[21]ASTM C597, 2004. Standard Test Method for Pulse Velocity through Concrete. Annual Book of ASTM Standards.

[22]ASTM C 805 - 97. Standard Test Method for Rebound Number of Hardened Concrete. Annual Book of ASTM Standards.

[23] ECP committee 269. (1962). "The Egyptian Code for Design and Construction of Concrete Structures", Housing and building research center, Giza, Egypt.

[24]ASTM C642, 2004. Standard Test Method for Density, Absorption, and Voids in Hardened Concrete. Annual Book of ASTM Standards

[25] Sengul, O., 2014. Use of electrical resistivity as an indicator for durability. Construction and Building Materials, 73, pp.434-441. 
[26] Rana, J. and Rughooputh, R., 2014. Partial Replacement of Fine Aggregates by Rubber in Concrete. Journal of Emerging Trends in Engineering and Applied Sciences (JETEAS), 5(5), pp.312-317.

[27] Abendeh, R., Ahmad, H.S. and Hunaiti, Y.M., 2016. Experimental studies on the behavior of concrete-filled steel tubes incorporating crumb rubber. Journal of Constructional Steel Research, 122, pp.251-260

[28] Ghasheir, F.M.A.B., Setyawan, A. and As'ad, S., 2016. THE RUBBERIZED CONCRETE FOR CRACK RESISTANT CONCRETE PAVEMENT. Jurnal Teknik Sipil, 2(2).

[29] Ho, A.C., Turatsinze, A., Abou-Chakra, A. and Vu, D.C., 2012. Rubberised concrete for the design of pavement on soil. International Journal of Materials Engineering Innovation, 3(2), pp.101-116.

[30] Bjegovic, D., Baricevic, A., Lakusic, S., Damjanovic, D. and Duvnjak, I., 2013. Positive interaction of industrial and recycled steel fibres in fibre reinforced concrete. Journal of Civil Engineering and Management, 19(sup1), pp.S50-S60.

[31] Fantilli, A.P., Mihashi, H., Vallini, P., 2009. Multiple cracking and strain hardening in fiber-reinforced concrete under uniaxial tension. Cement and Concrete Research 39(12), 1217-1229.

[32] RAO, K.J. and MUJEEB, M.A., 2013. Effect Of Crumb Rubber On Mechanical Properties Of Ternary Blended Concrete. Research and Development (IJCSEIERD), 3(3), pp.29-36.

[33] Ismail, M.K. and Hassan, A.A., 2016. Impact resistance and mechanical properties of selfconsolidating rubberized concrete reinforced with steel fibers. Journal of Materials in Civil Engineering, 29(1), p.04016193.

[34] Girskas, G. and Nagrockienè, D., 2017. Crushed rubber waste impact of concrete basic properties. Construction and Building Materials, 140, pp.36-42.

[35] ACI Committee 222. Protection of metals in concrete against corrosion, ACI 222R-01; 2001. p. 41.

[36] ASTM C 1760. Standard test method for bulk electrical conductivity of hardened concrete. West Conshohocken (PA): ASTM; 2012.

[37] Rostami, H, Lepore, J, Silverstrim, T, Zandi, I. Use of recycled rubber tyres in concrete. In: Proc. of the international conference. Concrete 2000 economic

and durable construction through excellence, vol. 2. Scotland, UK: University of Dundee; 1993. p. 391-399.

[38] Ristić, N., Topličić-Ćurčić, G. and Grdić, D., 2015. Abrasion resistance of concrete made with micro fibers and recycled granulated rubber. Zaštita materijala, 56(4), pp.435-445. 
Mohamed Ashour Mohamed, Investigation on improving rigid pavement properties by adding .......

دراسة في تحسين خواص الرصف الخرساني باضافة المطاط المعاد تدويره

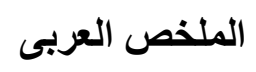

في هذه الدر اسة تم إجر اء اختبار ات مختلفة للتحقيق في نأثثير المطاط المعاد تدويره ليحل محل الركام الناعم

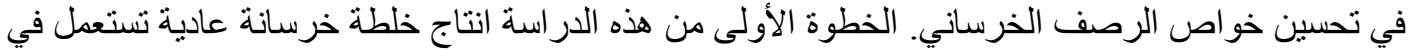

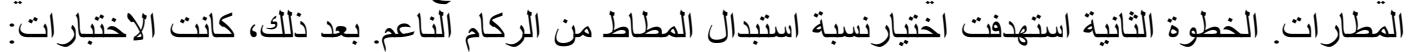

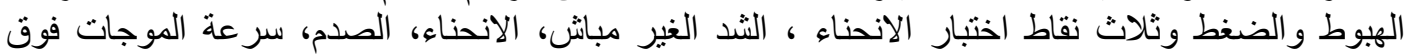

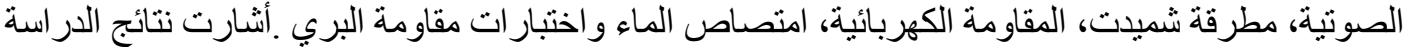

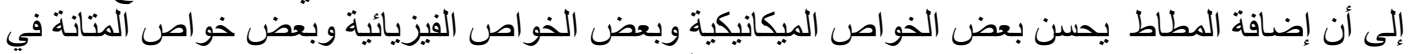
خصائص الرصف الخرساني باستثناء بعض الخو اص الأخرى حدث فيها انخفاض طفيف . 